\title{
Media Reform and Development in Bosnia: An Interorganizational Account of the Media Issues Group
}

Eric C. Martin*

Abstract:

This manuscript focuses on development assistance players' efforts to cooperate, coordinate and collaborate on projects of mutual interest. I target the case of the cross-sectoral and international Media Issues Group designed to reform and develop the media sector in Bosnia and Herzegovina. I identify and categorize variables that influenced interorganizational relationships to summarize lessons learned and potentially inform similar interventions. This work suggests that cooperation, coordination and collaboration are constrained by contextual, strategic and procedural variables. Through participant narrative based on observation and interviews, this work clarifies the nuances within these three sets of variables for potential extrapolation to other settings. Perhaps more importantly, it provides lessons learned that can inform future international community interventions in market development activities.

Keywords: International Development; Cross-Sectoral Cooperation; Media in Bosnia

JEL: O19; F35; F42

DOI: $10.2478 / v 10033-011-0008-9$

\section{Introduction}

This study examines an interorganizational international development assistance task force designed to help translate high-level policy objectives into groundlevel action through cooperative, coordinated and collaborative action. While programmatic lessons-learned, post-mortems and best practices are common, reports of administrative, organizational or interorganizational experiences in development settings are not, as they are often more prone for criticism and bad press. Which organization would really want to blame a programmatic failure on the inability of two individuals to work together, mismatched fiscal years, turf wars over beneficiaries, or the inability to agree upon a common agenda with their partners? Yet such seemingly manageable concerns can significantly and negatively influence development assistance. And that development assistance has significant influence over market development; in this case, the media market in Bosnia.

The primary focus of this manuscript is the ability, and inability, of development assistance players to cooperate, coordinate and collaborate on projects of mutual interest.
I target the case of the cross-sectoral and international Media Issues Group (MIG) designed to reform and develop the media sector (a typical activity in democracy assistance programs) in Bosnia and Herzegovina (hereafter referred to as Bosnia or $\mathrm{BiH}$ ). I identify and categorize variables that influenced interorganizational relationships (IORs) between development assistance organizations operating in Bosnia between 1995 and 2002, in an effort to summarize lessons learned and potentially inform similar interventions, of which there are plenty at present.

Nation building efforts in Kosovo, East Timor, Afghanistan, Iraq and Haiti present similar complexities: a massive international community presence, divided local populations, extreme institutional voids, post-conflict or disaster recovery, social, political, and economic
* Eric C. Martin
School of Management, Bucknell University
Lewisburg, Pennsylvania
E-mail: ecm018@bucknell.edu 
transitions and development. Programs within such complex humanitarian emergencies (CHEs) or nation building projects must coordinate among themselves, as well as between themselves and local stakeholders. In either case, cooperation, coordination and collaboration are constrained by contextual, strategic and procedural variables. The work reported below attempts to indentify some of the variables in an effort to improve both the giving and receiving of assistance.

Three main categories of variables present opportunities and obstacles to interorganizational action. The first is contextual. The environment or setting hinders many activities. Development professionals have relatively little control over these macro or external variables; Bosnian examples include the structure of the Dayton Peace Accords, ethnic division, the weak central government and presence of the UN protectorate government, etc. The second set of variables is strategic or policy oriented. Different development organizations have different, at times conflicting, goals, as do international and local host country players. It is difficult to agree on a common vision for the future across myriad policy arenas and choices among stakeholders with wildly divergent interests. The third category of variables is procedural in nature. These refer to the interactions between stakeholders that must negotiate their social order as they work through these difficult reforms that require interaction. Interorganizational, international and cross-sectoral relationships present a difficult dynamic. And yet the same issues and calls for improved coordination within the international community arise with each new CHE. The research question, therefore, guiding this work remains, what are the opportunities for and obstacles to cross-sectoral, international and interorganizational action?

\section{Medıa Development after Conflıct}

A sizable literature focuses on the role media does, should or might play in reform efforts; as an instrument of peace in challenging governmental positions, providing information, supporting elections, fostering civil society and enhancing democracy (Easterman, 2000; Gulyas, 2003; Jakubowicz 1995, 1996; Jamal, 2001, Jusic, et. al. 2000; Spurk, 2002; Taylor and Kent, 2000). These authors note both success and failures of media transition activities in Eastern Europe, touching upon themes of corruption, public acceptance, trust, legitimacy, and relations with both the state and previous regimes. They address media as both a positive force for change and a negative force that perpetuates conflict and helps obstruct reform efforts.

Several studies focus on actual international media reform efforts in $\mathrm{BiH}$ (Deluce, 2003; U.S. Government Accountability Office, 2005; Henderson, et. al., 2003; Stability Pact for South Eastern Europe, 2004; Taylor, 2000; United Nations Development Programme, 2004). These studies highlight four key areas of activity: journalism education, media business development, free speech and the protection of journalists, and the creation of associations and networks of media professionals designed to develop professional standards and codes of conduct, typically concluding that these are complex problems that cannot be solved by one organization or action. All four were being implemented in Bosnia at the time of this research (1995-2002).

Others explore more macro concerns regarding the role of media assistance efforts and their influence on Bosnian development and transition more broadly (Domi, 2002; International Crisis Group, 1997a, b; Internews, 2001; Jusic, 2000; Pech, 2000; Price, 2000; Shuey, 2003; Udovicic et al, 2001). They do address technical issues such as regulation of the airwaves to prevent ethnic hate propaganda, and the coordination of transmission frequencies, for example.

More importantly, this work targets the economic viability of media, the need for improved managerial practices regarding business development within local media outlets, and the role media plays in civil society development, institutional strengthening, ethnic relations and democracy-building efforts. For example, Taylor and Kent focused on the difference between alternative media and independent media (2000) and subsequent public perception. With alternative voices to state controlled media, confusion can arise over internationally supported media outlets and their objectivity. Others targeted the relationship between media and the various political power structures that are simultaneously evolving in transition states (Gulyas, 2003; Jamal, 2001; Palmer, 2001).

These accounts allude to the process through which the international development assistance community coordinates its activities, but do not explicitly target it. Relationships between international players are one of a number of structural concerns that influence program outcomes, which are typically of greater concern. This manuscript instead focuses explicitly on the process of relationship formation within the international 
community and the opportunities and obstacles it presents for the implementation of media reform efforts.

Research has addressed this interorganizational nature of development, highlighting the necessity and difficulty of coordinating policies and implementing programs within the international community and between international and domestic actors (Black, 1999; Brown, 2005; Martin and Miller, 2003). Several frameworks for interpreting such cross-sectoral coordination efforts have emerged (Aubrey, 1997; Brinkerhoff and Brinkerhoff, 2002; Brinkerhoff, 2002; Donini, 1996; Edwards, 1999; Evans 1996; Ostrom 1996; Westley and Vrandenburg, 1997) as have accounts detailing coordination efforts in response to the crisis in Rwanda, (Borton, 1995), peacekeeping in Afghanistan (Roberts and Bradley, 2005), environmental work in Madagascar (Brinkerhoff, 1996), women's groups in Costa Rica (Vargas, 2002), and privatization in Bosnia (Martin, 2004), to name a few. These efforts serve as exemplars for this research and help us better understand differences in settings, context, and environments.

Development in post-conflict situations is almost always "extreme" along multiple dimensions - by definition. It comes as no surprise then, that these situational variables and external jolts have a heavy bearing on organizational action. To overcome these constraints and obstacles, individual development agencies must cooperate, coordinate and collaborate with diverse partners to implement the desired reforms. Summaries of actual coordination mechanisms like that presented below across various settings (like those mentioned above) might help scholars and practitioners better conceptualize and contextualize development to ultimately improve the implementation of effective, efficient and equitable policy.

\section{Methods}

Interviews took place during two summer-long research field trips to Sarajevo in 1999 and 2000 and three one-month trips in 2003, 2004 and 2005. I met with representatives of all the organizations mentioned in this manuscript at least once during each visit (though the actual individual at times changed). I met with the director, deputy director and/or media director, or the person most responsible for media assistance (sometimes housed in democracy building departments, or economic development, etc) from the following organizations: Independent Media Commission (IMC); Open Broadcast
Network (OBN); Office of the High Representative (OHR); the Organization for Security and Cooperation in Europe (OSCE); the North Atlantic Treaty Organization (NATOSFOR), the European Union (EU); the United States' Embassy, Agency for International Development (USAID) and Office of Public Affairs (USOPA), as well as USAID contractors IREX and INTERNEWS; and regional think tank International Crisis Group (ICG).

In all, I interviewed 16 individual representatives of these organizations; nine on multiple occasions, two or three times, depending on their tenure over the period. These interviews were enhanced with nearly 100 other interviews with development professional related to media, for example, as a component of an economic development, human rights, or democracy building agenda. I explicitly ended each interview asking, "who are the other key players I should speak with along these lines?" I followed all of these leads and feel confident I spoke with all the key international stakeholders. This snowball sampling began with one media player and evolved into meeting all major players and actually sitting in on coordination meetings between these organizations. ${ }^{1}$

The long interview format was used. I coded interviews and observations in the field to shape subsequent questioning (Lofland and Lofland, 1995; McCracken, 1988; Strauss and Corbin, 1990). Initial coding efforts grouped responses by, for example, the subject's field experience, organizational type (local, bilateral, NGO, contractor) and focal area (protection of journalists, business development, regulatory work, etc.). Data were recoded several times into clusters of related concerns, at times emerging from the data, at times, based on reflection from related literature. It is here that the context, strategy and process grouping emerged. I integrated the initial codes into the context-strategyprocess framework and selected representative and/or divergent quotations to present for each key concern.

The key findings are reported in the following narrative under these three separate headings: 1 ) the context - the setting, the tasks and the players involved; 2) the strategy - what the group tried to achieve, what opportunities and obstacles presented themselves; and 3)

\footnotetext{
${ }^{1}$ While many of the international players I spoke with were, in fact, from the Balkans, they worked for and represented international organizations. I interviewed only a small handful of local Bosnian officials in various ministries. As such, I stress that this work is primarily about the international players in media sector reform. Also a reviewer pointed out that I did not speak with Council of Europe representatives.
} 
the process - actually working through the MIG to translate policy objectives into outcomes.

Context - The Setting, Tasks and Players:

Contextual concerns refer to variables associated with the development context, structure, environment or setting, including the particular organizations, past histories, individuals employed and current socioeconomic conditions. Participants often blamed their inability to work together on the unique complexities of Bosnia; i.e. the massive international response that brought hundreds of uncoordinated organizations to the tiny nation, the local divisions and complex structures of the Dayton Peace Agreement, and the deep-seated ethnic division resulting from the war to name a few. Contextual issues constrained strategic planning, which in turn influenced action, providing both an opportunity for and an obstacle to coordinated activity.

\section{Strategy - International Rationales for Working \\ Cooperatively}

Strategies refer to the policies, goals, ideas, and internal motivations of participants and partner organizations and their representatives that required cooperative, cross-sectoral and interdisciplinary solutions. Participants were keenly aware that given the size and scope of the tasks, they needed to work together for efficiency. Participants also knew that their work crossed organizational lines that would require partnerships. And finally, they knew that locals would take advantage of international divisions or differences in opinion. These realizations suggested to most that a coordinated response was of paramount importance, but the complexities that caused the divisions often hampered coordinated activity.

\section{Process - The Actual Coordination Efforts}

The third set of variables revolved around activities and processes that organizational representatives took toward cooperative activity - i.e. the actual workings and interactions of the Media Issue Group (MIG) members. While there were some successes, for the most part it remained difficult and many reported it 'unpleasant' to work together. This section provides an overview and understanding of the complexities and dilemmas of "development by committee." The context and strategies suggested the impetus and need to coordinate, but doing so proved more complex than it appears on paper.

\section{Analysis: The Case of the Media Issues Group}

The following participant narrative describes media reform efforts in Bosnia and the evolution of coordination among international players.

\section{4a. Context - The Setting, Tasks and Players}

Development professionals with experience across many diverse countries pointed to the particularly unique and onerous complexity of the situation here. Reforms in Bosnia took place against the backdrop of the Dayton Peace Accords and the difficult transition from central planning to a free-market democratic system. Respondents often commented on the constraints these conditions presented.

It is a transitional economy, (but unlike Eastern Europe) it never actually got the 1990 spirit of 'kill communism, let's go capitalism.' Second, there was a hideous war, aspects of which are still being uncovered every day. Third, the country was largely underdeveloped before any of this happened. Finally, you have the inability of the international community (IC) and its inconsistency, not speaking with one voice. (Contractor)

In media, the ethnic tensions were particular problematic. After the peace agreement, one multilateral official commented, "we had to take care of the political problem by giving every group their own channel." These nationalist broadcasters then more easily spread ethnic hatred over the air. The international community response was to reduce the relative power of the hate broadcasting by overloading the system with more mainstream, moderate and internationally supported outlets.

After Dayton the primary problem was the inflammatory TV. There was some bad stuff on. It was hate broadcasting. With elections coming, the IC poured money in everywhere to essentially multiply the number of voices in the hopes of drowning out the nasty ones. So you had this explosion of stations. (Multilateral) 
The strategy exacerbated two issues. First, nationalist political parties more easily controlled the smaller, supposedly independent, media outlets, buying influence and aggravating journalists until they followed the party line. "The number one pressure was economic. Tax police will come and visit you, or visit the people that are advertising on your station." (Multilateral)

Second, the number of broadcasters soon exceeded market capacity. The majority of stations became completely reliant upon donor support, and those that were independent simply couldn't compete. In 2000, there were about 300 stations for a market that could sustain comfortably perhaps 50 . As one official noted, "The market would flush out $80 \%$. If you took the grants away, unfortunately, some of the ones you would want to die wouldn't die." The international community soon found itself in the uncomfortable position of determining which stations would survive and which would not. Donors would have liked to only support those stations that conformed to their principles and political positions. However, "you never want to be a member of the donor state that says 'I think that station should stay alive and that one should close."' Regardless, the massive international influence here on market development is obvious.

Technical issues regarding frequency distribution represented a third primary concern in media, "to sort out the frequencies so bad guy $A$ was not jamming the frequency of good guy B or at least it was more organized." The OHR eventually developed its own independent regulatory agency (the IMC, with the aim that his would be eventually turned over to locals, and it was, in the form of the Communications Regulatory Agency). They developed a licensing process to limit political influence, strengthen the market by weeding out non-viable stations, and organize the distribution of frequencies.

They registered with us and we licensed them. In turn, they signed a code of practice. It was creating a relationship between a newly established regulator and broadcasters that had been working under a different system before, with broadcasters interfering with each other, getting licenses under the table, and paying draconian fees. There was no transparency. Nobody was trying to create a market. So we did tread on a few peoples' toes. (Multilateral)
In addition to these bedrock issues, programming on many stations was poor. Donor money was being wasted on weak stations that weren't supported by the public. Improved programming soon became a focal point for media development. One former editor lamented, "We had news bulletins consisting of one press conference after another, with no questions by the journalists and no attempt to go behind the story."

Attacks on journalists also threatened the development of an independent media. Journalists were poorly paid, ill supported by their stations and open to very serious threats, including bodily harm, if they criticized parties in power. This unacceptable situation concerned all internationals involved in media, spanning human rights, media, democratization, and election reform. Finally, reformers had to cope with the everpresent problems of local division and obstruction.

If you ask a local ministry what to fund in media, their answer will be exactly opposite from what you want to fund. (Bilateral)

The politics here are somewhat Byzantine ${ }^{2}$. There's never an end to a fight. It is one layer upon another of secrets and lies. Everyone here has a political agenda. Often those in charge do not see reconciliation as a solution. Separation is better and they want to encourage that. (Multilateral)

Furthermore, many international professionals had limited media and development experience before coming to Bosnia, and yet had enormous influence over media activities. Inexperienced players were criticized often. One contractor commented, "There isn't a great deal of depth of experience in either private or public broadcasting."

There have even been some criticisms in the local press that the international community should leave these well-intended and highly skilled Bosnian journalists alone and let them take care of their problems domestically. Then it went on to say the head of OHR media isn't a journalist, the head of the IMC isn't a journalist he is a judge, and OSCE's head is a Ph.D. in psychology. (Multilateral)

\footnotetext{
${ }^{2}$ A reviewer noted the use of this particular word as indicative of international community stereotypes of locals.
} 
4b. Strategy - International Rationales for Working Cooperatively

Many respondents broadly agreed that greater coordination was necessary; often pointing to general areas that lacked coordinated action as examples of need. However, the reasons for the lack of coordination differed greatly - with most blaming others for the inability to work together.

Realizing the need for improved cooperation and the recognition of failed actions progressed simultaneously. Respondents seemed unclear as to causality. For example, participants often criticized donor conferences for not being specific enough to actually coordinate implementation level activity. Instead, they coordinated funding and policy at very high levels. And, due to the general lack of coordination, more meetings were held. Criticisms of failed efforts served as a major motivator to better coordinate activity. Even within governments coordination problems were identified. One bilateral official commented that the "EU doesn't even talk to itself, let alone others."

USIS and USAID were supplying equipment to stations that were in direct competition with each other, which is not good since everyone here agrees that one of the objectives is to decrease the number of broadcasters. (Multilateral)

Difficulties in synthesizing different organizational mandates, responsibilities and goals were reported as the primary obstacles that prevented more effective coordination. One contractor suggested that, "some agencies work a bit autonomously without cooperation because they have different mandates, lords and masters."

A very weird market of donors exists. Donors are often at odds with each other, even different organizations or agencies controlled by one donor. They can actually have different objectives and since they don't tell each other what they are doing, we get international donors who are on the same side funding things that are totally at odds with each other. That needs to change. (Contractor)

Others were more optimistic about opportunities to coordinate and their desire to proactively make it happen.
I have to be transparent. I have to tell my constituents what the hell we are doing here anyway. As soon as a contract is signed with an organization, it's no longer confidential. So I don't have a problem in disclosing information. (Bilateral)

I have a mantra that is 'no competition, no repetition.' I am not going to do what you do and I really hope you are not going to do what I do. I would say it was received with something between skepticism and criticism. But I kept cooperating, but maintaining my boundaries. (Multilateral)

Respondents spoke of the potential value of information exchange, access to information and the need simply to learn more about each other's activities and the environment in which they operated.

We need to cooperate to avoid mistakes! It's triage. Some assistance organizations select the wrong stations to support. There were a lot of strong ties to Belgrade from before the war. Many stations had nasty pasts, and that is hard to uncover. It is often a surprise unless you work with others. (Bilateral)

Overwhelmingly, respondents suggested that the need to cooperate was propelled by dwindling funds and the waning importance of Bosnia on the international agenda. One contractor suggested, "the shortage of funds brings people to the table." But with the shortage of funds came other related changes. For example, changes in personnel greatly affected media reform efforts.

The gentleman who used to run media division was removed when the new High Representative arrived. He was a major proponent of OBN and a very strong defender. The person that replaced him doesn't support OBN. Also, he doesn't have nearly the power that the former guy did, so media has been chopped into public affairs and other areas. (Multilateral)

While media was extremely important in the years immediately following the war, at some point policy makers began to recognize the need for long-term sectoral stability. Activity increased, focusing on media as an industry and not just a tool to promote change, 
revealing the evolution of tasks from post-conflict to transition and development.

About the time that IMC began issuing provisional licenses, the IC forced the nasty stations to straighten up or took them off the air and they did fine people. They were very strict and very fair. So they got a lot of the bad voices off the air. Now the focus has changed to target the good stations that will likely survive and help them become more sustainable. (Bilateral)

Changes also resulted from increased removals of obstructionist locals, including significant political figures, like the president of the RS. These changes facilitated international action by removing those who caused the most problems, allowing more drastic reform measures.

The biggest motivator to coordinate and work together was to avoid wasting money and overlapping efforts. This motivator stemmed less from a desire to necessarily become more effective, than from the political sensitivities of working in media. Media development was a very visible activity that could have been decimated with bad perceptions on the part of constituents of how money was wasted.

If the US feels that they have core interest and a lot of experience developing the commercial market, and Europe has more interest in developing the public service, no problem. But let's not step on each other's toes. (Embassy)

Coordination was also mandated in some proposal and tendering processes, suggesting that the demand for coordination by others may have preceded the recognition of that same need by the field. Therefore, perhaps it was not that field level personnel overtly and independently made these recognitions based on their perceptions and experience, rather the seed was planted by headquarters and took time to disseminate out to field offices.

We have to include a section in our proposals about coordination, especially on larger projects, regarding who else is doing what. But it is difficult to keep track of your funding, you have to know exactly what you are funding, and if there is another donor, what they're funding. (Bilateral)
The need to speak in one voice and present a unified front to the Bosnians also represented an important motivator to work more closely together.

If they were to go out on a limb and OSCE didn't, that would be a problem. It would give the impression of a split and that would send signals (to the Bosnians) that we would rather not send. (Multilateral)

There is a general rule that internationals don't fight in front of nationals. If we have squabbles, we do it behind the scenes. It is like being in a family, there are things you do in the living room that you don't do on the street. (Multilateral)

While participants seemed certain that the need for one voice was paramount, few offered examples of problematic Bosnian reactions in instances where they did not speak in one voice. Therefore, it was difficult to determine whether this motivator was based on circumstance or cautious, preventative strategy.

In general, respondents agreed that the lack of an overall plan or strategy was a primary reason why coordination could not be achieved. However, that lack of consensus was also the very reason why coordination became such a necessity. An Embassy official lamented, "We are all just crushing ahead like a thunderous herd."

The fact that we don't have a coherent plan for the entire international community to follow is a major problem. (Bilateral)

The problem was the schizophrenic, and I don't use that word lightly, approach to identifying the (overall direction) for media development. (Contractor)

Differences also existed regarding the nature of basic media reform, especially between Americans and Europeans. Americans' concerns with First Amendment rights and the promotion of private media outlets set them apart from many other countries, often sparking great debate. However, the situation on the ground often precluded some American principles from practical consideration, like strict adherence to the First Amendment regarding potentially inflammatory speech in this tense environment. 
More fundamental issues existed, however, regarding basic differences in assistance ideology and culture. Americans were seen as more aggressive and more results oriented, willing to use strict conditionality and force through certain reforms. "The Americans are very direct, often willing to act unilaterally in light of what they perceive as national interest or, in their view, local interests from an American point of view." One contractor suggested that there was much more than an ideological or political rift between the Europeans and the Americans; "I think basically there is intense competition."

Overwhelmingly, respondents stressed funding as the major dimension across which EU and US organizations differ. The EU was notoriously slow, while the United States tended to pay immediately, once they had decided to fund a project. The funding issue tended to give Americans a bit more leverage and control. Because the Americans followed up on their plans and financed them, one multilateral official admitted, "We have to follow their policy." Many blamed the overly bureaucratic nature of the EU and its administrative arm, the European Commission, for such problems. Respondents suggested that 15 different bosses must approve aid from Europe, which turned minor revisions into major administrative operations.

\section{4c. Process - The Actual Coordination Efforts}

The MIG met biweekly and representatives of all the major media players (USAID, EU, OHR, OSCE, IMC as well as SFOR and UNHCR) attended regularly. "Every single media issue is discussed. It's a very long meeting, but it is very useful. That meeting is than mirrored back at very senior levels, ambassadorial levels, where the heads of missions meet to discuss bigger issues." (Bilateral)

Participation was a major issue revolving not only around actual levels of representation, but the skills and objectives of various representatives. For example, in the beginning, private contractors were not allowed to attend these meetings, which soon changed as the MIG gelled, representing an improvement since these contractors were often the key players in implementing specific reforms rather than the donor organizations that funded their work. However, at times, representatives simply were not appropriately informed or skilled for effective decision-making. Others reflected on levels of representation and the difficulties presented by political nuances.
You have to find your pecking order. You can go up a level and down a level and not up two levels, and down two levels only if you are kind. People are pretty unpretentious, but nonetheless these diplomatic courtesies have to be worked out. (Multilateral)

One official commented that she was "shocked at the level of comprehension of the embassy types. Their depth of understanding is a mile wide and an inch deep."

Several individuals mentioned that coordination in "media was easier (than other sectors) because there was a smaller group of people." Many organizations only interacted regularly with one or two other organizations. As a result, it was generally easy to get all of the important players together at the table. However, if one or two members did not attend, their absence greatly diminished the group's effectiveness.

Respondents generally were disappointed that media issues could not be coordinated through the Bosnians, because it hampered their efforts to transition control over to local authorities. In other countries it was logical to coordinate these things through their ministry, but that seemed impossible in Bosnia due to the internal ethnic divisions. "They would want you to fund everything you don't want to fund, and vice versa. They would want you to fund little political pet projects. You can't do that."

There may be some Bosnian natives at the table, but they are either the English speakers or just wired into the Western community. They aren't necessarily the right people to get real media change happening. (Contractor)

Concerns with local involvement emerged early in this discussion and continued to present obstacles to more effective coordinated action. Complaints revolved around the fact that some organizations were reluctant to share information. One bilateral official remarked, "I don't know why they wouldn't say how much or what, they are just cagey on money." Another said, "Organizations are guarded. To reveal is an invitation to leakage. Only under duress will they tell you where else they are receiving money from."

Some organizations don't want to share information because if details get to the press, it would become a pissing match. A Croat would say why is the US 
supporting that station and not me? And of course, you would have three renditions of that story. So a lot of organizations just don't like to say whom they support. (Bilateral)

Some mentioned a bit of organizational pride creeping into discussions, preventing more effective open dialog or exchange. One director suggested, "No organizational director worth his salt will acknowledge that another organization can do its tasks better than they can." While some suggested this was a result of overlapping mandates, others stressed the importance of individual personalities.

We set up a hotline for journalists. Well, another organization was outraged that we should do this. They thought they should do this. Eventually, we did turn it over to them. But if you look at their formal press, it says that they started this, no mention of the fact that we started it and turned it over to them. (Contractor)

They were irritated that we would consider getting involved in freedom of information and libel. The head of media there said to me once, 'whenever I turn around, there you are yapping at my heels.' (Contractor)

Occasionally, it seemed that representatives could not completely represent their national or organizational positions which created problems for the group because it seemed as though organizations had reversed positions at different levels.

The official contact that we have at the embassy may be totally on board with us, but the State Department may take a different position and we are like ok, where are the Americans today? (Bilateral)

Many recognized that problems stemmed from the basic bureaucratic nature of funding and programming on the part of all donors and implementers.

I don't know where the money comes from. It is filtered down maybe 6 or 7 layers from the time it left its original source to when it arrives at the broadcaster. Who knows where it has gone to get there. (Bilateral)
Despite such initial obstacles, the MIG met often and generally agreed to try to work together. However, it was difficult to set a common direction for action and even harder to commit resources to this alliance. Europeans and Americans simply had different views of media development.

There are different ideas about how to regulate the media. The US has a more 'free speech' slant than other countries that have stricter controls over their media. That was a big issue since we had advisors from different countries. (Bilateral)

Some respondents stressed that they were not able to go into enough detail to really address a common agenda or even begin to commit resources.

We couldn't get down to the nitty-gritty details. Everybody agrees on the general principles, but when it comes down to how it will actually work, there were significant disagreements. (Bilateral)

Others stressed their inability to allow national earmarked funds to be redirected by an international advisory group.

As such, it was difficult for some players to commit on behalf of their organizations. The level of flexibility or autonomy field offices had relative to their capitals played a significant role in such discussions. A US representative suggested that problems were often, "forced upon (him) by Congress. We work for taxpayers." As a result, "we get agreement at our level. Then at another level they reverse it. It is crazy. There is nothing you can do."

You can't have committees for everything. We are never going to allow US money to be put through a committee where someone else has veto power. That is virtually impossible to do. We have conditions that need to be met. (Bilateral)

The working level stiffs like me, we can't commit anything, so we live in this dual world where things are thrashed out at the middle levels, and then only when a crisis arises do the heads of the missions start to make decisions. (Contractor)

But they forged ahead regardless, recognizing that they could divide labor on some tasks and at least be well informed about where others were working and how 
overlaps might be avoided. Many suggested that they did work on the same issues often; they simply did them in separate ways. One contractor mentioned, "It works when we mutually serve a common agenda. We agree to a set of goals and then we each have a different sort of way to get there."

Working in the international community is like standing on the back of five stallions. Occasionally one is heading off in the other direction, but by and large the direction is agreed upon. (Embassy)

However, few participants could identify specific instances where this occurred. One contractor admitted, "Dividing labor is difficult since we really can't always agree on a common agenda." Another concurred, "There is not full agreement. That is the first reason why you wouldn't want to divide labor." As one participant put it, nobody can really commit to anything, instead, "it all simply comes down to good will and trust." One participant commented that he viewed their alliance largely as "de facto coordination, if then."

I looked at the landscape and saw how this was being carved up. I inherited a radio station, so it became natural that I would deal with radio. One thing just led to another. (Multilateral)

Others suggested the MIG was able to identify some areas where one or another player was more dominant. Organizations that dominated an area tended to be responsible for coordination of that area.

We did divide up the labor. OHR deals with policy on public broadcasting. The IMC deals with regulatory issues. OSCE deals with protection of journalists, development of media laws and journalist training. OSCE deals with radio, as opposed to OHR, which deals with TV. (Multilateral)

The group did feel as though they had worked together cooperatively in some instances. For example, respondents pointed to information exchange within the MIG as an important cooperative activity.

We talk about media development and the future of media and who's doing what. But it's more touching base. We go through current issues to keep each other informed and to coordinate to present a common public image. (Bilateral)

The group developed a database designed to detail which organizations were involved in which activities. Respondents often referred to this database as a potential success. Unfortunately, it was not updated regularly and many felt it would simply fade away for lack of interest. Aside from the database, some limited information exchange, general conversations regarding the future of media and discussion of potential new activities, most respondents felt that in general the meetings were not very effective, often stressing limits due to personalities and varying individual desires or efforts to cooperate.

Everyone would sit nice and say, 'well we are doing this and this' and some people would stay quiet and only later on would you find out who is really doing what. (Bilateral)

The effort to shut down EROTEL was reported as the single most important and one of only two specific examples of impressive coordination and cooperation mentioned by nearly all of the major players. EROTEL was the biggest and most illegal Croatian broadcaster in the country. The international community, after much negotiation, decided to shut it down. But this action did not materialize in a formalized manner; instead it developed out of a variety of dyadic and somewhat informal personal connections only loosely connected to the actual MIG.

Removing EROTEL took a lot of coordination between OHR, OSCE, SFOR, IMC and AID. I mean we had to make the high representative decide. We had to get a letter from OHR and push it to the highest levels within the US government. There was always the potential of protests and destabilization. Eventually, SFOR raided mountaintops and disconnected feeds. That was a very sensitive process. We had to work well with everyone to get that done, at the highest and lowest levels. There was potential for great miscommunication, but due to diligent efforts, we were able to pull that off. That was coordination. (Multilateral)

Aside from such an impressive coordinated action, the second main tangible output of coordinated activity was the production of papers and reports. While many 
commented on the value of information exchange, these reports seemed to unify the group even more and were, occasionally, proudly displayed in some offices. Others focused instead on the weaknesses in the reports and the political maneuvers that surrounded its production.

The donors asked for a paper to be written on how OBN could be sucked into the PBS system as a news provider. OHR will write that. But OSCE will also have a hand in it because the OSCE-run radio station may also be sucked into PBS. IMC is involved because we have a regulatory view on the transmission systems around the country. So it will be written by all of us. Unfortunately, you know the old adage, a camel is a racehorse designed by a committee. (Multilateral)

\section{Discussion}

Coordinating activity in complex, divided and troubled areas provides an opportunity to combine what we know about management, interorganizational collaboration and the more technical aspects of peacekeeping and development. This work identified specific opportunities for and obstacles to coordination in this difficult setting in order to help improve the transfer and delivery of service in unsettled, uncertain and extremely fluid democracy-building settings.

Hundreds of countries currently deploy thousands of people and spend billions of dollars supporting international development and peacekeeping operations throughout the world. Unfortunately, reports and field studies suggest great service overlap, inefficiencies and waste in these international efforts (Brahimi, 2000; Donini, 1996; Martin and Miller, 2003; Summers, 2000). This case was no exception. Many practitioners and politicians cited the lack of cooperation and coordinated activity as the primary culprit in ineffective programs and initiatives. However, blanket calls to simply 'improve' coordination are equally problematic. Improving coordination under such circumstances is complex.

Much of the complexity reported here results from the fact that this situation reaches beyond 'media reform' 'development' or even 'peacekeeping.' This is indeed democracy- or nation-building. But the job is not being implemented, nor even being directed, by a single organization. These efforts are the product of a vast network of disparate players that must work together intimately, communicate constantly, and coordinate minute aspects of seemingly disparate tasks. The boundary lines between players, countries, tasks and objectives blur. In addition, success often required cooperation among reluctant, if not obstructionist, partners. Few practitioners had the vision, legitimacy or power necessary to translate high-level strategy into ground-level implementation requiring collective action among highly autonomous organizations. Furthermore, in this international arena, no clear hierarchy existed. Instead, various aspects of the strategy had independent hierarchies, with many of the same organizations often serving different roles in different task settings. And relationships among international organizations and between the internationals and locals were not clearly defined.

Cooperative activity does not always mean overt efforts towards compromise and sharing. Maintaining clear boundaries and working in isolation based on an orderly division of tasks can be a very productive output from IORs. Perhaps most importantly, it simply takes time to allow such relationships to mature - and in postconflict situations many tasks, like media reform in particular, must be implemented urgently, without the luxury of time.

Cooperative interorganizational activity is perhaps more difficult in environments where organizations value accountability and caution over efficiency and risk. As such, it may explain why IORs in the private sector receive so much attention and typically serve as models for public or cross-sectoral cooperation. Such efforts may be misguided. Public, NGO and cross-sectoral cooperation presents a difficult and complex environment within which IORs do not inherently flourish. Greater thought must accompany calls for cooperation in such chaotic settings. In addition, attention should be paid to differences between cooperation, coordination and collaboration. What type of IOR is right for which activity? Since the complex, turbulent and conflict-laden environment in Bosnia influenced strategic planning and decision-making, action was often based on the context of the situation (i.e. feasibility), rather than being based on the actual needs of beneficiaries. In addition, the real beneficiaries of development assistance were removed from the decision-making process, which became problematic. 


\section{Conclusions}

I highlighted three sets of variables that constrained cooperative, coordinated and collaborative activity regarding media reform in Bosnia. The participant narrative helped contextualize the situation in an effort to make these findings more relevant to other similar interventions throughout the world. While the details of the stories will change, I suspect practitioners and observers of nation building activities in Kosovo, Afghanistan and Iraq will identify similarities. Indeed, recent reports from Haiti stress the same pattern evident early in Bosnia's development story - a massive international presence; a weak host government; competition among implementing agencies; a near complete absence of local institutions; sketchy early results, funding delays and administrative hurdles and impending donor fatigue within just six months. A development official working in Afghanistan (and a key informant on this paper) commented to me recently that the situation in Kabul was "worse than Bosnia ever was" with respect to coordination within the international community and between internationals and locals. The lessons from Bosnia should be documented and shared. It represents a distinct early archetype of a new era of nation building experiments largely led by the United States and the European Union.

Context. The stakeholders I interviewed had little control over the environment in which they worked. However, the context within which they worked was the result of earlier efforts made during the "conflict" stage, for example, in the Dayton Peace Accord negotiations. That a compromised peace solution created complexities down the road for development may have been unavoidable. But the temporal flow and connectivity between reforms at different phases should be considered. Detailed accounts of development settings could help practitioners and scholars develop a typology of development settings. Complex humanitarian emergences (CHEs) and post-conflict situations are often chaotic. Though each case is of course unique, similarities can be found. On some dimensions, for example, the situation in Kosovo mimics the situation in Bosnia. Across other dimensions, Haiti seems remarkably similar to Bosnia. These dimensions can be clarified and catalogued. Researchers should document changes in the environment over time, and return to former hotspots over time to determine the long term outcome of these policies and programs. Lessons learned from Bosnia's reconstruction might provide more insight for practitioners in Haiti, for example, with the benefit of a fifteen year perspective.

Strategy. While most strategic decisions will be based on a case-by-case basis, some ideological perspectives could be clarified and discussed within the international community. For example, USAID identified cluster competitiveness as a theme to guide economic development for some years. International community partners should adopt, modify or oppose each others' anchoring perspectives at conferences, in nonemergency task forces and within academic outlets journals such as this, as well as conferences. Cluster competitive gave way to value creation over time. Are these fads or strategic evolutions in approach? For example, one of the initial responses, in the case reported above, to the problem of hate broadcasting was to increase the number of stations in the country in the hopes of crowding out the hate with more positive messages. This spawned competition and market saturation in short order, necessarily forcing improved licensing and frequency distribution. Was the interim strategy to increase the number of voices a positive incremental step necessary while the regulatory agency developed capacity or did it only waste donor money by temporarily increasing media outlets, further burdening the licensing and frequency distribution problem once they were up and running, and create more work for regulators? Or, was the short term effect of this interim strategy positive in other political, social and economic dimensions? The lack of a guiding vision for various sectors makes improvisation based on perceived realities on the ground difficult.

Process. Many respondents pointed to the lack of an overarching vision for media sector reform. This was largely due to the lack of leadership within the international community. If USAID was the lead agency, their media strategy would dominate. However, OHR, OSCE, USAID, OBN and IMC all claimed the "lead" on various aspects of this work. Coordination need not result in centralization, but most stakeholders in this process were indeed calling for centralization. When a host country doesn't develop its own strategic plan for the future, which internationally developed plan should be adopted? The UN's OHR, charged with implementing the civilian aspects of the DPA seems like the logical choice. However, most development assistance agencies viewed OHR negatively; they lacked skills, local knowledge and experience in such extreme settings and proved more 
reactionary then proactive. In addition, implementing agencies followed donor priorities, and thus when forced to choose between OHR and Washington or Brussels, the choice was clear.

Many obstacles to effective reform efforts lie not in the actual circumstances and dilemmas of development, where attention is often focused, but in the organizational and managerial dilemmas of "development by committee." It is here that organizational mandates, administrative procedures, organizational cultures and institutional logics tend to obscure potentially successful collaborative implementation mechanisms. Sharing knowledge about best practices in such cooperative experiences might help practitioners move beyond "redeveloping wheels" in each new country they target. $[$.

\section{References}

Aubrey, L., 1997, The politics of development cooperation: NGOs, gender and partnerships in Kenya. NY: Routledge.

Black, J.K., 1999, Development in Theory and Practice. Oxford: Westview Press.

Borton, John, 1995, 'An account of co-ordination mechanisms for humanitarian assistance during the international response to the 1994 crisis in Rwanda', Disasters, Overseas Development Institute, Vol. 20, No. 4, pp. 305-323.

Brahimi, L., 2000, Report on the Panel on United Nations Peace Operations.

Brinkerhoff, D.W., 1996, 'Coordination issues in policy implementation networks: An illustration from Madagascar's environmental action plan', World Development Vol. 24, No. 9, pp. 14971510.

Brinkerhoff, J.M., 2002, 'Government-Nonprofit partnership: A defining framework', Public Administration and Development, Vol. 22, pp. 19-30.

Brinkerhoff, J.M. and Brinkerhoff, D.W., 2002, 'GovernmentNonprofit relations in comparative perspective: Evolution, themes and new directions', Public Administration and Development Vol. 22, pp. 3-18.

Brown, S., 2005, 'Foreign Aid and Democracy Promotion', European Journal of Development Research Vol. 17, No. 2, pp. 179-198.

De Luce, Dan, 2003, Assessment of USAID Media Assistance in Bosnia and Herzegovina, 1996-2002, Bureau for Policy and Program Coordination, PN-ACR-756.

Domi, Tanya, 2002, Analysis of Media Reforms, PBS in Bosnia, Montenegro and Serbia, Media Online/Radio Free Europe/Radio Liberty.

Donini, A., 1996, 'The Politics of Mercy: UN Coordination in Afghanistan,

Mozambique, and Rwanda', Occasional Paper \# 22 (Providence, R.I.: Watson Institute.

Easterman, M., 2000, 'One-legged Media, Lame Democracy: Experiences from Albania and Bosnia,' International Journal of Cultural Studies Vol. 3, No. 2, pp. 240-246.

Edwards, M., 1999, 'International development NGOs: Agents of foreign aid or vehicles for international cooperation?', Nonprofit and Voluntary Sector Quarterly Vol. 28, No. 4, supplement pp. 25-37.
Evans, P., 1996, 'Introduction: Development strategies across the public-private divide', World Development Vol. 24, No. 6, pp. 1033-1037.

Government Accountability Office (GAO), 2005, Independent Media Development Abroad: Challenges Exist in Implementing U.S. Efforts and Measuring Results, Report to the Chairman, Committee on Foreign Relations, U.S. Senate, GAO-05-803.

Gulyas, A., 2003, 'Print Media in Post-Communist East Central Europe,' European Journal of Communication Vol. 18, No. 1, pp. 81-106.

Henderson, G., Kilalic, J. and Kontic, B., 2003, The Media Environment in Bosnia and Herzegovina: An Assessment for USAID/Bosnia.

International Crisis Group, 1997, Media in Bosnia and Herzegovina: How International Support Can Be More Effective, ICG Bosnia Project, March 18.

International Crisis Group, 1997, Dayton: Two Years On, ICG Bosnia Project Report No. 27, November, 19.

Internews B\&H Sarajevo, 2001, Pressures on Electronic Media in BiH: Findings of the First Comprehensive Study, Canadian International Development Agency.

Jamal, A., 2001, 'State-Building and Media Regime: Censoring the Emerging Public Sphere in Palestine,' Gazette Vol. 63, No. 2-3, pp. 263282.

Jakubowicz, K., 1995, 'Media Within and Without the State: Press Freedom in Eastern Europe', Journal of Communication Vol. 45, No. 4., pp. 125-139.

Jakubowicz, K., 1996, 'Media Legislation as a Mirror of Democracy,' Transitions Vol. 2, No. 21, October.

Jusic, Tarik, 2000, Media Policies and the Settlement of Ethnic Conflicts, in Managing Multiethnic Local Communities.

Lofland, J. and Lofland, L.H., 1995, Analyzing social settings. Wadsworth Publishing, CA.

Martin, E., 2004, 'Privatization in Bosnia and Herzegovina: Insights from and into the craft of interorganizational process analysis', Organization Studies Vol. 25, No. 7, pp. 1115-1157.

Martin, E. and Miller, J., 2003, 'Developing Bosnia and Herzegovina: Understanding Large-Scale Interorganizational Systems', Voluntas. June 2003.

McCracken, G., 1988, The long interview. Sage Publications. CA.

Ostrom, E., 1996, 'Crossing the great divide: Coproduction, synergy and development', World Development Vol. 24, No. 6, pp. 1073-1087.

Palmer, L.K., 2001, Power-Sharing in Media: Integration of the Public? MediaOnline: Southeast European Media Journal.

Pech, Laurent, 1999/2000, 'Is Dayton Falling?: Reforming Media in Bosnia and Herzegovina, International Journal of Communications Law and Policy, Issue 4, Winter, pp. 1-28.

Price, Monroe, 2000, Restructuring the Media in Post-Conflict Societies, UNESCO World Press Day Conference, Geneva, Cardozo Online Journal of Conflict Resolution.

Pressman, J.L. and Wildavsky, A., 1984, Implementation $3^{\text {rd }}$ Edition. University of California Press, CA.

Roberts, N.C. and Bradley, R.T., 2005, 'Organizing for Peace Operations', Public Management Review Vol. 7, No. 1, pp. 111-134.

Shuey, A., 2003, 'Democracy According to Dayton: The United States and International Community's Role in Bosnia-Hercegovina, International Affairs Review, pp. 110- 118.

Spradley, J.P., 1979, The ethnographic interview. Harcourt Brace Jovanovich, Fort Worth.

Spurk, C., 2002, Media and Peacebuilding Concepts, Actors and Challenges, KOFF Working Paper No. 1. Swiss Peace Foundation

Stability Pact for South Eastern Europe, 2004, Support to Media in SEE: Strategy 2005-2007, Media Task Force.

Strauss, A. and Corbin, J., 1990, Basics of Qualitative Research. Sage Publications, CA. 
Taylor, M., 2000, Final Evalaution of OTI's Programs in Bosnia and Croatia: An Evaluation Prepared for the Office Of Transition Initiatives Bureau for Humanitarian Response, USAID. September 26.

Taylor, M., 1999, 'Media relations in Bosnia: A role for Public relations in Building Civil Society', Public Relations Review Vol. 26, pp. 1-15.

Taylor, M., and Kent, M., 2000, 'Media Transitions in Bosnia: From Propagandistic Past to Uncertain Future', Gazette Vol 62, No. 5, pp. 355378.

Udovicic, Z., Jusic, T., Halilovic, M, Udovicic, R., 2001, The Media at a Turning Point: A Media Landscape of Bosnia-Herzegovina, MediaOnline: Southeast European Media Journal.

United Nations Development Programme, 2004, Supporting Public Service Broadcasting: Lessons from Bosnia and Herzegovina's Experience, Bureau for Development Policy, Democratic Governance Group.

Vargas, C.M., 2002, 'Women in sustainable development: Empowerment though partnerships for healthy living', World Development Vol. 30, No. 9, pp. 1539-1560.

Westley, F. and Vrandenburg, H., 1997, 'Interorganizational collaboration and the preservation of global diversity', Organization Science Vol. 8, No. 4, pp. 381-403. 